\title{
ACRL to Conduct Salary Survey
}

The Association of College and Research Libraries will conduct a survey of compensation structures of librarians in post-secondary education for the academic year 1975/76. The survey, supported by a grant from the Council on Library Resources, will be conducted by Richard J. Talbot, director of libraries, University of Massachusetts, Amherst, a member of ACRL's Committee on Academic Status and Ann von der Lippe also of the University of Massachusetts.

The survey is designed to collect valid and reliable data on the salaries and fringe benefits of librarians working in college and university libraries in order to update the third survey $(1972 / 73)$ on salaries prepared by Donald F. Cameron and Peggy Heim for the Council on Library Resources and to enable comparisons of the compensation structures of academic librarians and faculty members and comparisons among academic librarians.
Questions to be addressed by the survey will be: (1) How much improvement has occurred in the economic status of librarians since the 1972/73 survey? (2) How do salaries and rates of compensation of academic librarians compare with those of the classroom faculty? Data will also be collected on the numbers of women and minorities employed in academic libraries and their rates of compensation.

Questionnaires will be mailed on December 1 to all academic libraries in institutions participating in the surveys of compensation conducted by the American Association of University Professors. Preliminary reports of the findings will be available in July 1976. The final report will be published in October 1976.

A limited supply of copies of previous surveys $(1969 / 70,1970 / 71,1972 / 73)$ are still available from the Council on Library Resources, Inc., One Dupont Circle, NW, Suite 620, Washington, DC 20036.

\section{Tentative Schedule}

\section{of ACRL Meetings at Midwinter}

This schedule lists only those ACRL meetings scheduled as of October 10,1975. No additions or corrections made after that date appear in this list.

Midwinter Meeting

Chucago, Illinois

JANUARY 18-24, 1976

\section{Sunday, January 18}

2:00-4:00 p.m.

Rare Books and Manuscripts Section Executive Committee

8:30-10:00 p.m.

Choice Editorial Board

Monday, January 19

8:00-9:30 a.m.

Asian and African Section Executive Committee

College \& Research Libraries Editorial Board

ACRL Legislation Committee

ACRL Publications in Librarianship Editorial Board

University Libraries Section Executive Committee

10:00 a.m.-12:00 noon

ACRL Board of Directors
Western European Language Specialists Discussion Group

12:30-1:30 p.m.

Asian and African Section Nominating Committee

2:00-4:00 p.m.

ACRL Academic Status Committee

Agriculture and Biological Sciences Section Executive Committee

ACRL Bibliographic Instruction Task Force

ACRL Budget and Finance Committee

ACRL Constitution and Bylaws Committee

ACRL Goals, Priorities and Structures Subcommittee

ACRL Publications Committee

Rare Books and Manuscripts Section Manuscripts Collections Committee

ACRL Standards and Accreditation Committee

4:30-6:00 p.m.

Agriculture and Biological Sciences Section Executive Committee

ACRL Goals, Priorities and Structures Subcommittee

ACRL Publications in Librarianship Editorial Board 